\title{
MENSTRUAL PERIOD ANALISIS OF WOMEN PLWHA WITH ANTI RETROVIRAL THERAPY (ART) IN NGO LANCANG KUNING PEKANBARU CITY
}

\author{
Dona Martilova, Husna Farianti Amran
}

\author{
Program Studi D-III Kebidanan STIKes Payung Negeri Pekanbaru \\ e-mail:dhonalova@gmail.com
}

\begin{abstract}
Acquired Immunodeficiency Syndrome (AIDS) is caused by Human Immunodeficiency Virus (HIV), including infectious diseases that cause weakness of the immune system. Riau province on the 11st grade of most cases of AIDS that is 1104 cases and 53\% occur in women. Treatment that can be done is to use antiretroviral therapy (ART). ARV drugs do not kill the virus but can slow the growth of the virus. The use of antiretroviral drugs can cause side effects in some women the use of antiretroviral drugs causes menstrual disorders such as prolonged bleeding, menstrual bleeding time, faster menstrual periods, longer menstrual intervals, and, periods sometimes do not occur. The research type is quantitative with cross sectional approach. The study was conducted from May to December 2017. The study population was all women living with HIV / AIDS under the guidance of NGO Lancang Kuning Pekanbaru which amounted to 96 people with a sample of 53 people taken with Simple Random Sampling technique (simple random), Instrument data collection is a questionnaire in the form of a list question and checklist list. Data were analyzed by Univariate to know the frequency distribution of respondent, and Bivariate (chi-square) to know the relation between variables. The results showed that menstrual cycle disorders in HIV-positive women were associated with age (P value 0.001), duration of use of antiretroviral therapy (P value 0.004), nutritional status of women living with HIV (P value 0,003) and environmental factor (P value 0,000). It is recommended that women living with HIV / AIDS can take Anti retroviral medication regularly and maintain their nutritional status in good condition and it is expected that the environment can provide support to PLHIV women
\end{abstract}

Keyword: Haid Period, Women (PLWHA), Antiretroviral (ARV)

\section{PENDAHULUAN}

Acquired Immunodeficiency

(AIDS) disebabkan oleh Human Immunodeficiency Virus (HIV), termasuk penyakit infeksi yang mengancam jiwa karena mengakibatkan kelemahan sistem imun. Nasronudin. (2007).

United Nations Programme on HIV/AIDS (UNAIDS) pada tahun 2013 melaporkan secara global hingga tahun 2012 tercatat sekitar 35,3 juta orang di dunia menderita HIV. Dengan angka kematian akibat AIDS sebanyak 1,6 juta orang. UNAIDS. (2013).

Provinsi Riau berada pada urutan ke-11 seluruh Indonesia, dengan jumlah kasus AIDS sebanyak 1.104 kasus per September 2014. Data KPA Povinsi Riau dari 12 kabupaten kota Pekanbaru berada diurutan pertama. Temuan kasus HIV yaitu 295 kasus (47\%) pada laki-laki dan 333 kasus (53\%) pada perempuan. Sementara kasus AIDS terdapat perbedaan yang mencolok yaitu 160 kasus (26\%) pada laki-laki dan 454 kasus (74\%) perempuan. Kondisi ini menggambarkan bahwa jumlah kasus HIV pada perempuan semakin meningkat.
Penanganan yang dapat dilakukan terhadap infeksi HIV adalah dengan menggunakan terapi antiretroviral (ART). Obat ARV tidak membunuh virus akan tetapi ARV dapat memperlambat pertumbuhan virus. Penanganan nasional antiretroviral (ART) diterbitkan oleh Departemen Kesehatan RI sebagai standar penatalaksanaan ART di Indonesia. (Spiritia. 2014)

Penggunaan ARV dapat menimbulkan efek samping diantaranya kelelahan, anemia, masalah pencernaan, masalah kulit dan masalah tulang. Pada beberapa perempuan penggunaan ARV dapat menyebabkan gangguan haid seperti perdarahan yang berlangsung lebih lama, perdarahan waktu tidak haid, masa haid yang lebih cepat, interval haid yang lebih lama, dan, haid kadang kala tidak terjadi. (Noviana, 2013)

Dikota Pekanbaru terdapat 8 Lembaga Swadaya Masyarakat (LSM) yang yang bergerak dalam bidang kemasyarakatan kususnya HIV/AIDS (ODHA). Dari 8 LSM tersebut yang langung berinteraksi dengan ODHA adalah Lembaga Swadaya Mayarakat (LSM) Lancang kuning. 
Berdasarkan uraian di atas, maka dari itu peneliti tertarik untuk mengangkat judul "Analisa Siklus Haid Pada Wanita ODHA Dengan Terapi Antiretroviral (ART) Di Lembaga Swadaya Masyarakat (LSM) Lancang Kuning Kota Pekanbaru"

\section{METODOLOGI PENELITIAN}

Jenis penelitian adalah kuantitatif dengan pendekatan cross sectional. Penelitian dilakukan pada Mei sampai Desember 2017. Populasi penelitian adalah seluruh ODHA wanita yang berada dibawah pembinaan LSM Lancang Kuning Pekanbaru yang berjumlah 96 orang. Dengan sampel berjumlah 53 orang diambil dengan teknik Simple Random Sampling (acak sederhana). Instrument penelitian adalah kuesioner berupa daftar pertanyaan untuk mengetahui variabel dukungan lingkungan dan daftar checklist untuk mengetahui usia, dan lama penggunaan ARV serta pengukuran berat badan dan tinggi badan untuk mengetahui indeks massa tubuh (IMT).

Analisa Data yang digunakan adalah analisa Univariate untuk mengetahui distribusi frekuensi responden, analisa Bivariate (chi-square) untuk mengetahui hubungan antar variabel.

\section{HASIL DAN PEMBAHASAN}

Hasil

1. Analisis Univariate

Tabel 1. Distribusi Frekuensi

Karakteristik Responden di LSM Lancang

Kuning Pekanbaru tahun 2017

\begin{tabular}{lll}
\hline Kategori & Jumlah & $\%$
\end{tabular}

2. Analisis Bivariate

a. Hubungan Usia Reproduksi dengan Siklus Haid Wanita ODHA

Tabel 2 Hubungan Usia dengan Siklus Haid Wanita ODHA

\begin{tabular}{|c|c|c|c|c|c|c|}
\hline & & \multicolumn{2}{|c|}{ Siklus Haid } & \multirow[b]{2}{*}{ Total } & \multirow[b]{2}{*}{ P Value } & \multirow[b]{2}{*}{ OR $(95 \%$ CI $)$} \\
\hline & & Teratur & $\begin{array}{c}\text { Tidak } \\
\text { Teratur }\end{array}$ & & & \\
\hline \multirow[b]{2}{*}{ Usia Reproduksi } & Usia Reproduksi & $8(27,6 \%)$ & $5 \quad(72,4 \%)$ & $29(100 \%)$ & \multirow[b]{2}{*}{0.001} & \multirow[b]{2}{*}{$\begin{array}{c}9.975(2.779 \\
35.809)\end{array}$} \\
\hline & $\begin{array}{c}\text { Bukan Usia } \\
\text { reproduks }\end{array}$ & $19(79.2 \%)$ & $21(20.8 \%)$ & $24(100 \%)$ & & \\
\hline \multicolumn{2}{|c|}{ Total } & $27(50.9 \%)$ & $26 \quad(49.1)$ & $\begin{array}{c}53 \\
(100 \%)\end{array}$ & & \\
\hline
\end{tabular}

Sumber: Analisis data Primer, 2017

\begin{tabular}{|c|c|c|}
\hline $\begin{array}{l}\text { Usia } \\
\text { Reproduksi }(20-35 \\
\text { tahun) } \\
\text { Bukan usia } \\
\text { Reproduksi } \\
(<20 \text { tahun atau }>35 \\
\text { tahun) }\end{array}$ & $\begin{array}{l}29 \\
24\end{array}$ & $\begin{array}{l}54,7 \\
45,3\end{array}$ \\
\hline $\begin{array}{l}\text { Jangka Waktu } \\
\text { Penggunaan ART } \\
>2 \text { tahun } \\
<2 \text { tahun }\end{array}$ & $\begin{array}{l}25 \\
28\end{array}$ & $\begin{array}{l}47,2 \\
52,8\end{array}$ \\
\hline $\begin{array}{l}\text { Status Gizi } \\
\text { IMT Normal } \\
\text { IMT tidak normal }\end{array}$ & $\begin{array}{l}32 \\
21\end{array}$ & $\begin{array}{l}60,4 \\
52,8\end{array}$ \\
\hline $\begin{array}{l}\text { Lingkungan ODHA } \\
\text { Medukung } \\
\text { Tidak Mendukung }\end{array}$ & $\begin{array}{l}24 \\
29 \\
\end{array}$ & $\begin{array}{l}45,3 \\
54,7\end{array}$ \\
\hline $\begin{array}{l}\text { Riwayat Keturunan } \\
\text { Ya } \\
\text { Tidak }\end{array}$ & $\begin{array}{l}55 \\
45 \\
\end{array}$ & $\begin{array}{l}55 \\
45 \\
\end{array}$ \\
\hline $\begin{array}{l}\text { Siklus Haid } \\
\text { Teratus } \\
\text { Tidak Teratur } \\
\end{array}$ & & $\begin{array}{l}50,9 \\
49,1 \\
\end{array}$ \\
\hline $\begin{array}{l}\text { Berdasarkan } \\
\text { diketahui bahwa mayo } \\
\text { pada usia reproduksi ( } \\
(54,7 \%) \text {, telah meng } \\
\text { yaitu } 28 \text { orang ( } 52,8 \% \\
\text { (IMT normal) yaitu } 32 \\
\text { ODHA tidak menc } \\
\text { lingkungan yaitu } 29 \\
\text { Berdasarkan hasi } \\
\text { bahwa mayoritas wa1 } \\
\text { antiretroviral di } \\
\text { Pekanbaru memiliki s } \\
\text { orang }(50,9 \%)\end{array}$ & $\begin{array}{l}-35 \\
\text { unak } \\
\text { mer } \\
\text { rang } \\
\text { patk } \\
\text { ng }\end{array}$ & $\begin{array}{l}\text { univariate } \\
\text { HA berada } \\
\text { itu } 29 \text { orang } \\
<2 \text { tahun } \\
\text { tus gizi baik } \\
\text {, dan wanita } \\
\text { angan dari } \\
\text { diketahui } \\
\text { ngan terapi } \\
\text { g Kuning } \\
\text { tur yaitu } 27\end{array}$ \\
\hline
\end{tabular}


Dari tabel diketahui terdapat hubungan yang signifikan antara usia reproduksi dan siklus haid wanita ODHA dengan $P$ value sebesar $0,001(\mathrm{P}<$ 0,05). OR (Odds Ratio) 9.975 dan dengan CI (Confidence Interval) 95\% antara 2.779 sampai 35.809. Hasil penelitian ini menunjukkan wanita ODHA yang berada pada usia reproduksi sehat mengalami siklus haid lebih teratur 9.7 kali dibandingkan wanita ODHA yang bukan pada usia reproduksi sehat.

nyata terhadap nilai kadar air, $F_{\text {hitung }}>F_{\text {tabel }}$ (lampiran 4) pada taraf kepercayaan 95\% maka
$\mathrm{H}_{0}$ ditolak, untuk melihat perbedaan tersebut maka dilanjutkan dengan uji Tukey. Hasil uji Tukey menunjukkan bahwa nilai kadar airmasing-masing perlakuan berbeda nyata kecuali untuk perlakuan A28 dan C28.

Kadar abu dari sampel pakan ikan fermentasi dianalisis menggunakan metode gravimetri. Hasil analisis kadar abu sampel pakan ikan fermentasi dapat dilihat pada tabel 3 .

\section{b. Hubungan Penggunaan ART dengan Siklus Haid Wanita ODHA}

Tabel 3 Hubungan Penggunaan ART dengan Siklus Haid Wanita ODHA

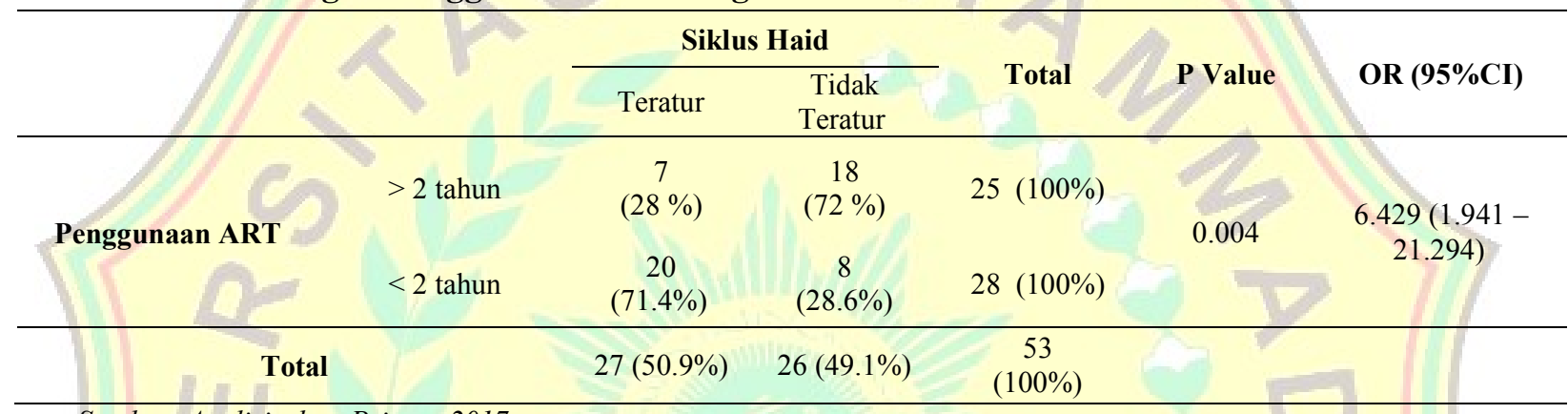

Sumber: Analisis data Primer, 2017

Dari tabel diketahui bahwa terdapat hubungan yang signifikan antara penggunaan ART dan siklus haid wanita ODHA dengan $P$ value sebesar $0,004(\mathrm{P}<0,05)$. OR (Odds Ratio) 6.429 dan dengan CI (Confidence Interval) 95\% antara 1.941 sampai 21.294. Hal ini menunjukkan wanita ODHA yang menggunakan ART $>2$ tahun mengalami siklus haid lebih teratur 6.4 kali dibandingkan yang menggunakan ART $<2$ tahun.

c. Hubungan Status Gizi dengan Siklus Haid Wanita ODHA

Tabel 4 Hubungan Status Gizi dengan Siklus Haid Wanita ODHA

\begin{tabular}{|c|c|c|c|c|c|c|}
\hline & \multicolumn{3}{|c|}{ Siklus Haid } & \multirow[b]{2}{*}{ Total } & \multirow{2}{*}{ P Value } & \multirow{2}{*}{$\begin{array}{l}\text { OR } \\
(95 \% C I)\end{array}$} \\
\hline & & Teratur & $\begin{array}{l}\text { Tidak } \\
\text { Teratur }\end{array}$ & & & \\
\hline \multirow{2}{*}{ Status Gizi } & IMT Normal & $\begin{array}{l}22 \\
(68.8 \%)\end{array}$ & $\begin{array}{l}10 \\
(31.2 \%)\end{array}$ & $\begin{array}{l}32 \\
(100 \%)\end{array}$ & & \multirow{2}{*}{$\begin{array}{l}7.040(2.013 \\
-24.618)\end{array}$} \\
\hline & $\begin{array}{l}\text { IMT Tidak } \\
\text { Normal }\end{array}$ & $\begin{array}{l}5 \\
(23.8 \%)\end{array}$ & $\begin{array}{l}16 \\
(76.2 \%\end{array}$ & $\begin{array}{l}21 \\
(100 \%)\end{array}$ & & \\
\hline Total & & $\begin{array}{l}27 \\
(50.9 \%)\end{array}$ & $\begin{array}{l}26 \\
(49.1 \%)\end{array}$ & $\begin{array}{l}53 \\
(100 \%)\end{array}$ & & \\
\hline
\end{tabular}

Sumber: Analisis data Primer, 2017

Dari tabel diketahui bahwa terdapat hubungan yang signifikan antara status gizi dan siklus haid wanita ODHA dengan $P$ value sebesar 0,003 $(\mathrm{P}<0,05)$. OR (Odds Ratio) 7.040 dan dengan CI (Confidence Interval) 95\% antara 2.013 sampai 24.618. Hal ini menunjukkan wanita ODHA dengan IMT Normal mengalami 
siklus haid lebih teratur 7 kali dibandingkan wanita ODHA dengan IMT tidak normal.

d. Hubungan Faktor Lingkungan dengan Siklus Haid Wanita ODHA

Tabel 5 Hubungan Status Gizi dengan Siklus Haid Wanita ODHA

\begin{tabular}{|c|c|c|c|c|c|c|}
\hline & & \multicolumn{2}{|c|}{ Siklus Haid } & \multirow[b]{2}{*}{ Total } & \multirow[b]{2}{*}{ P Value } & \multirow[b]{2}{*}{$\begin{array}{l}\text { OR } \\
(95 \% C I)\end{array}$} \\
\hline & & Teratur & $\begin{array}{l}\text { Tidak } \\
\text { Teratur }\end{array}$ & & & \\
\hline $\begin{array}{l}\text { Faktor } \\
\text { Lingkungan }\end{array}$ & $\begin{array}{l}\text { Tidak } \\
\text { Didukung } \\
\text { Mendapat } \\
\text { Dukungan }\end{array}$ & $\begin{array}{l}23 \\
(79.3 \%) \\
4(16.7 \%)\end{array}$ & $\begin{array}{l}6(20.7 \%) \\
20 \\
(83.3 \%)\end{array}$ & $\begin{array}{l}29(100 \%) \\
24(100 \%)\end{array}$ & 0.000 & $\begin{array}{l}19.167 \\
(4.727 \\
77.716)\end{array}$ \\
\hline Total & & $\begin{array}{l}27 \\
(50.9 \%) \\
\end{array}$ & $\begin{array}{l}26 \\
(49.1 \%)\end{array}$ & $\begin{array}{l}53 \\
(100 \%) \\
\end{array}$ & & \\
\hline
\end{tabular}

Sumber: Analisis data Primer, 2017

Dari tabel diketahui bahwa terdapat hubungan yang signifikan antara factor lingkungan dan siklus haid wanita ODHA dengan $P$ value sebesar $0,000(\mathrm{P}<0,05)$. OR $($ Odds Ratio) 19.167 dan dengan CI (Confidence Interval) $95 \%$ antara 4.727 sampai 77.716 . Hal ini menunjukkan wanita ODHA dengan factor lingkungan yang mendapat dukungan mengalami siklus haid lebih teratur 19 kali dibandingkan yang tidak mendapat dukungan.

\section{Pembahasan}

\section{a. Hubungan Usia dengan Siklus Haid Wanita ODHA}

Berdasarkan hasil penelitian diketahui bahwa terdapat hubungan yang signifikan antara usia reproduksi dan siklus haid wanita ODHA dengan $P$ value sebesar $0,001(\mathrm{P}<0,05)$. Hasil penelitian menunjukkan wanita ODHA yang berada pada usia reproduksi mengalami siklus haid lebih teratur 9.7 kali dibandingkan wanita ODHA yang bukan pada usia reproduksi.

Pada usia reproduksi terjadi keseimbangan hormonal pada wanita yang akan mempengaruhi siklus haid. Dimana siklus haid berhubungan dengan teori hipotalamus-hipofise. Haid adalah perdarahan periodik dan siklik dari uterus yang dimulai sekitar 14 hari setelah ovulasi secara berkala akibat terlepasnya lapisan endometrium uterus. (Bobak, 2006)

Seiring dengan pertambahan usia maka akan terjadi perubahan pada hormonal wanita yang secara langsung mempengaruhi siklus haid wanita.

Wanita HIV-positif dapat mengalami permasalahan haid, akan tetapi kelainan haid yang dialami bukan merupakan gangguan haid yang berat. Wanita HIV-poitif dapat mengalami ketidakteraturan haid yang ringan. Namun para peneliti juga menemukan bahwa gangguan haid tersebut dapat juga dialami oleh wanita HIVnegatif yang sama secara demografis. Wanita HIV-positif tidak berisiko lebih tinggi terhadap masalah haid yang berat. Bahkan para peneliti ini menambahkan bahwa wanita HIV-postif yang dapat merasa tenang dan nyamankan dengan kondisi mereka tidak akan menimbulkan gangguan yang berat dalam siklus haid mereka sampai penyakit HIV itu menjadi lebih lanjut. Akan tetapi, usia wanita semakin tua akan mempengaruhi siklus haid mereka dan akan terjadi perubahan pada siklus haid mereka. Penelitian membuktikan wanita yang berusia rata-rata 35 tahun. Hasilnya mungkin berbeda dengan perempuan yang lebih lanjut usianya. Tentunya infeksi HIV dan ART mungkin mempunyai dampak yang berbeda pada masalah haid mereka ketika mendekati masa mati haid. (Santoro N, 2005)

ODHA yang berada pada usia remaja juga akan mengalami ketidakteraturan menstruasi, dimana siklusnya dapat maju ataupun mundur beberapa hari. Hal ini karena menstruasi juga dipengaruhi dengan kondisi fisik remaja. Dimana 
hormon-hormon seksual belum stabil, semakin dewasa siklus menstruasi remaja putri semakinteratur walaupun bisa maju atau mundur beberapa hari, karena faktor kecemasandan kelelahan. (Aden, 2010 dalam Kolin \& Indrawati, 2013).

\section{b. Hubungan Waktu Penggunaan ARV dengan Siklus Haid Wanita ODHA}

Dari hasil penelitian diketahui bahwa terdapat hubungan yang signifikan antara penggunaan ART dan siklus haid wanita ODHA dengan $P$ value sebesar 0,004 Hasil penelitian ini menunjukkan wanita ODHA yang menggunakan ART $>2$ tahun mengalami siklus haid lebih teratur 6.4 kali dibandingkan wanita ODHA yang menggunakan ART $<2$ tahun.

Penanganan yang dapat dilakukan terhadap infeksi HIV adalah dengan menggunakan terapi antiretroviral (ART). Terapi Antiretroviral (ART) berarti mengobati infeksi HIV dengan beberapa obat antiretroviral (ARV). ARV tidak membunuh virus akan tetapi ARV dapat memperlambat pertumbuhan virus. (Spiritia. 2014).

Obat antiretroviral (ART) merupakan pengobatan HIV pada umumnya. ART digunakan untuk menghambat perkembangan HIV. Penelitian membuktikan bahwa penggunaan Antiretroviral (ART) telah banyak menekan angka kematian akibat masalah terkait AIDS. Pengobatan HIV juga disertai dengan pemberian obat immunomodulator yang bekerja untuk meningkatkan fungsi daya tahan tubuh. Kombinasi pengobatan antivirus dan obat immunomodulator diharapkan dapat memberikan hasil yang lebih baik. HIV sangat cepat bermutasi sehingga resisten terhadap obat. Untuk mengurangi kemungkinan tersebut umumnya obat anti HIV diberikan dalam bentuk kombinasi. Obat antiretroviral (ART) yang digunakan untuk menghambat perkembangan HIV adalah golongan nukleosida dan non-nukleosida inhibitor enzim reverse transcriptase (RT) dan inhibitor protease. (Santoro N, 2005)

Penggunaan ART dalam jangka waktu lebih lama mengakibatkan penurunan pada risiko timbulnya kelainan haid. Hal ini kemungkinan terjadi karena seiring dengan berjalannya waktu maka secara keseluruhan kesehatan perempuan ODHA akan semakin membaik. Kelainan siklus haid sangat berkaitan dengan jumlah CD4. Massad, et all 2006 berpendapat bahwa perempuan yang sudah dalam kondisi sakit berat (dengan jumlah CD4 yang lebih rendah) mungkin berisiko lebih tinggi untuk mengalami kelainan pada siklus haid. Penggunaan ART sebagai upaya pengobatan tidak memiliki dampak langsung pada siklus haid. Perempuan HIV-positif dengan CD4 di bawah 200 dilaporkan lebih banyak masalah haid dibandingkan mereka dengan CD4 di antara 200 sampai 500. Penggunaan ART juga tidak dikaitkan langsung dengan kelainan haid tertentu. Akan tetapi peggunaan golongan obat ART yang berbeda dapat berdampak pada kelainan haid, perempuan ODHA yang menggunakan protease inhibitor dapat mengalami perdarahan yang lebih berat selama Haid. (Massad, 2206)

Dalam penelitian yang diterbitkan dalam Journal J Womens Health (2006) menjelaskan kejadian kelainan haid adalah $<20 \%$. serostatus HIV tidak berhubungan dengan gangguan menstruasi umum. Pada wanita HIV-seropositif dengan jumlah CD4 yang lebih tinggi akan mengalami lebih sedikit masalah dibandingkan dengan perempuan dengan jumlah CD4 <200 / $\mathrm{mm} 3$, pada perempuan dengan jumlah 200-500 / $\mathrm{mm} 3$, rasio odds ( OR) untuk amenore adalah $0,55, \mathrm{p}=0,02$, dan untuk oligomenore adalah $0,54, p=0,0003$; untuk perempuan dengan jumlah $>500 / \mathrm{mm} 3$, OR untuk amenore adalah $0,67, p=0,14$, dan untuk oligomenore adalah $0,55, p=0,001$. serostatus HIV tidak dikaitkan dengan kelainan insiden.

\section{c. Hubungan Status Gizi dengan Siklus}

\section{Haid Wanita ODHA}

Status gizi berhubungan dengan siklus haid wanita ODHA. Hasil penelitian menunjukkan wanita ODHA dengan IMT Normal mengalami siklus haid lebih teratur 7 kali dibandingkan wanita ODHA dengan IMT tidak normal.

Kondisi kesehatan wanita dapat dilihat dari status gizinya, status gizi digolongkan dalam status gizi kurang, normal atau lebih. Ukuran kegemukan dapat dilihat dari ukuran berat badan yang diukur dengan menggunakan timbangan 
berat badan. Kegemukan terjadi apabila berat badan seseorang melebihi berat badan ideal. (Budiyanto, 2002)

Salah satu cara untuk mengukur kegemukan adalah dengan menggunakan rumus IMT (Indeks Massa Tubuh) atau Body Mass Indeks (BMI) yaitu jika nilainya lebih 27 per $\mathrm{kg} / \mathrm{m}^{2}$. Pengukuran antropometri diperoleh dengan membandingkan Berat Badan ( $\mathrm{kg}$ ) dibandingkan dengan kuadrat dari tinggi badan (meter). (Harahap.H, dkk, 2005)

Kegemukan dapat dipengaruhi oleh pola konsumsi (WHO,2005), dan berhubungan dengan faktor sosial, ekonomi dan psikologi. Terjadinya kegemukan juga berhubungan dengan aktivitas fisik seseorang. Umumnya orang yang kurang melakukan aktivitas fisik, maka cenderung mengalami peningkatan berat badan. Kondisi ini diperburuk dengan gaya hidup dalam pemilihan jenis dan jumlah makanan yang dikonsumsi. (Rajagopalan, 2003)

Pada penderita HIV AIDS risiko kegemukan jarang terjadi, hal yang sering terjadi adalah penurunan berat badan yang diakibatkan menurunnya fungsi dan daya tahan tubuh. Asuhan gizi merupakan komponen penting dalam perawatan individu yang terinfeksi HIV. Penderita HIV akan mengalami penurunan berat badan dan hal ini berkaitan erat dengan kurang gizi. Penyebab kurang gizi bersifat multifaktoral antara lain karena kurang nafsu makan, gangguan penyerapan sari makanan pada alat pencernaan, hilangnya cairan tubuh akibat muntah dan diare dan gangguan metabolisme. Akibat gangguan kesehatan umum penderita HIV cepat menurun, sekitar 97\% ODHA menunjukkan kehilangan berat badan sebelum meninggal. Kehilangan berat badan tiak dapat dihindarkan sebagai konsekuensi dari infeksi HIV. Jika seorang dengan infeksi HIV mempunyai status gizi yang baik maka daya tahan tubuh akan tetap baik sehingga memperlambat masuk ke tahap AIDS. Spiritia,(2014).

Asuhan gizi dan terapi medis juga penting bagi ODHA bila menggunakan terapi antiretroviral (ARV). Makanan yang dikonsumsi mempengaruhi penyerapan ARV dan obat infeksi oportunistik. Dan sebaliknya penggunaan ARV-
01 harus dikonsumsi saat lambung kosong, akan tetapi beberapa obat lainnya tidak. Pegaturan diet dapat juga digunakan untuk menguragi efek ARV-O1. Spiritia,(2014).

Wanita yang mengalami kekurangan maupun kelebihan gizi akan berdampak pada penurunan pada fungsi hipotalamus. Sehingga apabila produksi FSH dan LH terganggu, maka siklus menstruasi juga akan terganggu. Jika dihubungkan dengan mestruasi jumlah wanita yang mengalami anovulasi akan meningkat apabila berat badan mengalami perubahan (meningkat atau menurun) Felicia, Hutagaol.E, Kundre.R (2015)

Syndrom wasting juga dapat dikaitkan dengan HIV dan diketahui berdampak pada siklus haid. Penelitian yang dilakukan oleh Steven Grinspoon, MD dan rekan menemukan bahwa diantara 31 perempuan HIV-positif dengan berbagai tingkatan wasting $20 \%$ mengalami amenorea. Penelitian ini juga mengungkapkan tingkat amenorea lebih tinggi pada perempuan dengan berat badan dibawah $90 \%$ dari berat ideal. (spiritia, 2014)

\section{d. Hubungan Lingkungan dengan Siklus} Haid Wanita ODHA

Dari hasil penelitian diketahui bahwa terdapat hubungan yang signifikan antara factor lingkungan dan siklus haid wanita ODHA. Wanita ODHA yang mendapat dukungan dari lingkungan mengalami siklus haid lebih teratur 19 kali dibandingkan wanita ODHA yang tidak mendapat dukungan dari lingkungan.

Faktor lingkungan merupakan hal yang dapat melatabelakangi gangguan siklus haid pada wanita. Kendala dalam pengendalian penyakit HIV/AIDS salah satunya adalah stigma dan diskriminasi dari lingkungan terhadap penderita HIV/AIDS. Survey nasional menemukan bahwa diskriminasi pengobatan orang yang hidup dengan HIV terus terjadi di berbagai aspek kehidupan. (Brouard, 2006)

Bentuk stigma yang didapatkan dari lingkungan khususnya teman terkait dengan stress bagi penderita HIV adalah kecanggungan dan perhatian secara berlebihan. Oleh karena itu, beberapa peneliti menyarankan untuk merahasiakan status HIV seseorang. Stress akan 
lebih meningkat apabila hal itu ditunjukkan oleh dari anggota keluarga. Sengagupta (2011)

Menurut penelitian LSM Yayasan Spiritia di Indonesia, menunjukkan ODHA yang mengalami stigma, paling banyak mendapatkan stigma dari dokter $12,5 \%$ dan paling sedikit mendapatkan stigma dari lingkungan. Diskriminasi dari lingkungan rumah sakit atau puskesmas mencapai 7,2\%. Lembaga yang diharapkan memberikan perawatan dan dukungan, pada kenyataannya masih memberikan stigma dan diskriminasi. Spiritia (2014)

Penelitian lain juga menunjukkan bahwa buruknya efek stigma yaitu dapat menyebabkan depresi berat pada penderita yang dapat menurunkan kualitas hidupnya hingga 2.7 kali lebih rendah dan akan menjadi lebih sulit untuk sembuh bahkan menjadi lebih rentan terhadap serangan penyakit lainnya dan didukung pula imunitas yang berkurang drastis akibat HIV (Charles et al, 2012).

Stess yang meningkat akibat kurangnya dukungan dari lingkungan atau stigma negatif yang didapat oleh ODHA akan berdampak pada siklus haid ODHA. (Hawari dalam Saryono, 2011).

Gejala- gejala stress pada diri seseorang seringkali tidak disadari karena perjalanan awal tahapan stress timbul secara lambat. Dan baru dirasakan bilamana tahapan gejala sudah lanjut dan mengganggu fungsi kehidupannya seharihari baik dirumah, di tempat kerja ataupun di pergaulan lingkungan sosialnya (Kusmiran, 2011).

\section{KESIMPULAN}

Kesimpulan, siklus Haid Wanita ODHA berhubungan dengan Usia, Lama Penggunaan ART, Status Gizi dan Lingkungan.

\section{DAFTAR PUSTAKA}

Bobak, M.Irene. et.al (2006). Buku Ajar Keperawatan Maternitas. Edisi. Alih Bahasa: Maria A. Wijayarini.Jakarta. EGC

Budiayanto (2002). Obesitas dan Perkembangan Anak, Jakarta; Grafindo Perkasa
Charles, B, Jeyaseelan, L, Pandian, A. K, Sam, A. E, Thenmozhi, M, \& Jayaseelan, V. (2012). Association Between Stigma, Depression and Quality of Life of People Living with HIV/AIDS (PLHA) in South India- a Community Based Cross Secctional Study. BMC Public Health. (Online). Diakses tanggal 24 april 2015

Depkes RI. (2006). HIV/AIDS dan Pencegahannya. Ditjen PP\&PL. Jakarta

Felicia, Hutagaol.E, Kundre.R. E-Journal Keperawatan Vol.3. Nomor.1 (2015)

Harahap, H, Widodo, S, dan Mulyati,S (2005).

Penggunaan berbagai cut-off Indeks

Massa Tubuh Sebagai indikator obesitas terkait penyakit degeneratif di Indonesia, Gizi Indonesia

Kusmiran, Eny. (2011). Kesehatan Reproduksi Remaja dan Wanita. Jakarta; Penerbit Salemba Medika

Kemenkes. RI. (2013). Laporan Situasi Dan Perkembangan HIV AIDS Di Indonesia Tahun 2013. Ditjen PP\&PL. Jakarta

Kolin, Indrawati.(2013).Hubungan Tingkat Stress dengan Gangguan Menstruasi Pada Remaja Mahasiswa Akbid Abdi Husada Semarang Semester II Tingkat I Tahun 2013. Diperoleh tanggal 10-112016 dari http://webcache.googleusercontent.com/s earch?q=cache:r29OSVkvugkJ:jurnal.abd ihusada.ac.id/index.php/jurabdi/article/do wnload $/ 35 / 35+\& c d=1 \&$ hl $=\mathrm{id} \& \mathrm{ct}=\mathrm{clnk} \& \mathrm{c}$ lient $=$ firefox-b

Laporan Upaya Penanggulangan HIV\&AIDS Di Kota Pekanbaru Tahun 2014. Komisi Penanggulangan AIDS Kota Pekanbaru

Lapau Buchari, (2013). Metode Penelitian Kesehatan. Buku Obor. Jakarta

Massad LS, Evans CL, Minkoff H, et al. Effects of HIV infection and its treatment on selfreported menstrual abnormalities in women. Journal of Women's Health 2006 Jun;15(5):591-8.)

Noviana, N. 2013. Kesehatan Reproduksi dan HIV/AIDS. Jakarta ; CV Trans Info Media 
Nasronudin. (2007). HIV\&AIDS Pendekatan Biologi Molekuler, Klinis Dan Sosial. Airlangga University Press. Surabaya

Pierre Brouard,(2006). Center for the Study of AIDS/University of Pretoria, and Caroline Wills, POLICY/South Africa. United States Agency for International Development (USAID). (Online). Diakses tanggal 9 Mei 2017

Rajagopalan, S (2003), Nutrition Chlengges in the next decade. Food and Nutrition bulletin, Vol 24, No.3, Tokyo: The United Nation University

Spiritia,(2014). Seri lembaran informasi HIV/AIDS. berdasarkan terbitan The AIDS InfoNet. Lihat http:// www.aidsinfonet.or. Diakses tanggal 19 mei 2017

Sengupta.S, Banks.B, Jonas.D, Miles.M, Smith.C. (2011). HIV Interventions to Reduce HIV/AIDS Stigma: A Systematic Review. PMC. (Online). Diakses tanggal 3 Mei 2017
Sastroasmoro S, Ismael S. Dasar-dasar metodologi penelitian klinis. Jakarta: Sagung Seto; 2008.

Satari MH, Wirakusumah FF. Konsistensi penelitian dalam bidang kesehatan. Bandung: Refika Aditama; 2011.

Spiritia,(2014). Seri lembaran informasi HIV/AIDS. berdasarkan terbitan The AIDS InfoNet. Lihat http:// www.aidsinfonet.or. Diakses tanggal 19 mei 2017

Santoro N, Arnsten JH, Buono D, et al. Impact of street drug use, HIV infection and highly active antiretroviral therapy on reproductive hormones in middle-aged women. Journal of Women's Health 2005 Dec;14(10):898-905.

UNAIDS. (2013). Global Report: UNAIDS report on the global AIDS epidemic 2013.WHO Library Cataloguing in Publication Data.,

World Health Oranization, (2005), Nutrition in adolesence-issues and Challenges for the Health sector, Geneva: WHO 